\author{
JOURNAL OF MARINE RESEARCH AND TECHNOLOGY \\ journal homepage: https://ojs.unud.ac.id/index.php/JMRT \\ ISSN: 2621-0096 (electronic); 2621-0088 (print)
}

\title{
Karakteristik Mikroplastik Pada Ikan Laut Konsumsi Yang Didaratkan Di Bali
}

\author{
Samantha Julia Blandina Lumban Tobing ${ }^{\text {a }}$, I Gede Hendrawan ${ }^{\text {a*}}$, Elok Faiqoh ${ }^{\text {a }}$ \\ ${ }^{a}$ Program Studi Ilmu Kelautan, Fakultas Kelautan dan Perikanan, Universitas Udayana, Bali, Indonesia \\ *Corresponding author, email:gede.hendrawan@unud.ac.id
}

\section{ARTICLE INFO}

\section{Article history:}

Received: July $13^{\text {th }} 2020$

Received in revised form: August $7^{\text {th }} 2020$

Accepted: August $21^{\text {th }} 2020$

Available online: August $31^{\text {th }} 2020$

Keywords:

Microplastics

Plastic

Waste

Fish

\section{ABSTRACT}

Studies over the past decade have shown that microplastics are widespread in marine environments, at sea level, on coastlines, and the seabed. Microplastic sources come from small particles used in the cosmetic industry and plastic industry base materials. Other microplastic sources emerge through the degradation of larger pieces of plastic in the environment due to physical and chemical processes, caused by light, heat, oxygen, water, and organisms. Microplastics tend to be digestible by marine organisms and potentially transferred to higher trophic organisms through the food chain, and thus toxic pollutants will potentially harm marine organisms and even humans through bioaccumulation and biomagnification. This research was conducted to determine the characteristics of microplastics that pollute marine fish consumption that is landed in Bali. Samples were gathered from traditional fishermen who landed their catch in Bali. Microplastic is identified in the digestive tract of fish. The samples of fish obtained by Decapterus spp (Selayang), Auxis Rochei (tongkol), Rastrelliger spp (kembung), and Sardinella lemuru (Lemuru). 39 fish out of the total identified 89 fish were found to be contaminated with 69 microplastics (fiber, fragments, film) and 1 mesoplastic (fragment). The size of the plastic found is between 0.32 to $22 \mathrm{~mm}$. The abundance of microplastics in fish caught in Bali's waters is 0.78 (SD 1.15) particles/fish. The finding of microplastics in the digestive tract of fish caught by traditional fishermen in Bali is feared to have the potential to harm marine organisms and even humans through the process of bioaccumulation and biomagnification.

2020 JMRT. All rights reserved.

\section{Pendahuluan}

Mikroplastik merupakan potongan potongan kecil dari plastik yang berukuran $<5 \mathrm{~mm}$ (Arthur et al., 2009). Studi dalam beberapa dekade terakhir telah menunjukkan bahwa mikroplastik tersebar luas di lingkungan laut dan kelimpahannya telah meningkat sejak 1960-an (Lusher et al., 2013). Mikroplastik hampir ada di mana-mana pada lingkungan laut, membentang dari wilayah kutub sampai ke garis khatulistiwa, dari wilayah pantai yang terpencil hingga daerah pantai yang padat dengan penduduk, dari perairan terbuka hingga laut dalam (Wang et al., 2016). Sumber mikroplastik dibagi menjadi dua, yaitu sumber primer dan sumber sekunder (Andrady AL, 2011). Sumber primer dari mikroplastik berasal dari partikel kecil yaitu jenis pelet yang digunakan dalam industri kosmetik dan yang digunakan sebagai bahan dasar industri plastik. Sumber sekunder mikroplastik berasal dari degradasi plastik yang berukuran makro di lingkungan akibat proses fisik dan kimia, yang dapat disebabkan oleh cahaya, panas, oksigen, air, dan organisme (Browne MA, 2015).

Mikroplastik kemungkinan besar akan dicerna oleh organisme laut dan berpotensi ditransfer ke organisme tingkat trofik yang lebih tinggi melalui rantai makanan (Andrady AL, 2011), dan dengan demikian polutan beracun akan berpotensi membahayakan organisme laut dan bahkan manusia melalui bioakumulasi dan biomagnifikasi (Wang et al., 2016). Penelitian mengenai karakteristik mikroplastik pada daerah feeding ground pari manta Nusa Penida oleh Argeswara et al. (2019) menunjukkan bahwa dari keseluruhan sampel mikroplastik, jenis mikroplastik terbanyak ditemukan adalah jenis fragmen, film, fiber dan jenis foam. Penelitian lainnya menunjukkan bahwa jenis mikroplastik fiber ditemukan dominan pada saluran pencernaan ikan lemuru protolan hasil tangkapan di Selat Bali (Yudhantari et al., 2019) yang kemungkinan berasal dari material sintetik pada pakaian dan juga alat tangkap seperti pancing atau jaring.

Produksi sampah di Bali per hari mencapai 4.281 ton dimana $11 \%$ di antaranya terbawa ke laut yang dikhawatirkan akan dikonsumsi oleh manusia melalui konsumsi spesies laut yang telah terkontaminasi oleh mikroplastik sebagai makanan yang dapat berdampak potensial pada kesehatan manusia (Bali Partnership, 2019). Setelah tertelan, penyerapan mikroplastik di distribusi melalui sistem peredaran darah dan masuk ke dalam jaringan dan sel, hal ini berpotensi menghasilkan beberapa efek samping (Barboza et al., 2018). Konsumsi mikroplastik dapat menyebabkan obesitas dan kanker, dalam kasus wanita, mikroplastik dapat menyebabkan kanker payudara (GESAMP, 2015). Maka dari itu, penting halnya untuk melakukan penelitian mengenai karakteristik kandungan mikroplastik yaitu jenis, jumlah dan ukuran mikroplastik yang ada pada saluran pencernaan ikan yang didaratkan di Bali. Penelitian ini dilakukan 
untuk mengetahui karakteristik mikroplastik yang mencemari ikan laut konsumsi yang didaratkan di Bali.

\section{Metode Penelitian}

\subsection{Waktu dan Tempat Pengambilan Sampel}

Pengumpulan sampel ikan dilakukan pada bulan Februari sampai Maret tahun 2020. Sampel ikan diambil di daerah pendaratan ikan nelayan tradisional yang ada pada 7 kabupaten di provinsi Bali yaitu Kabupaten Badung, Buleleng, Gianyar, Jembrana, Karangasem, Klungkung, Tabanan dan Kota Denpasar (Gambar 1).

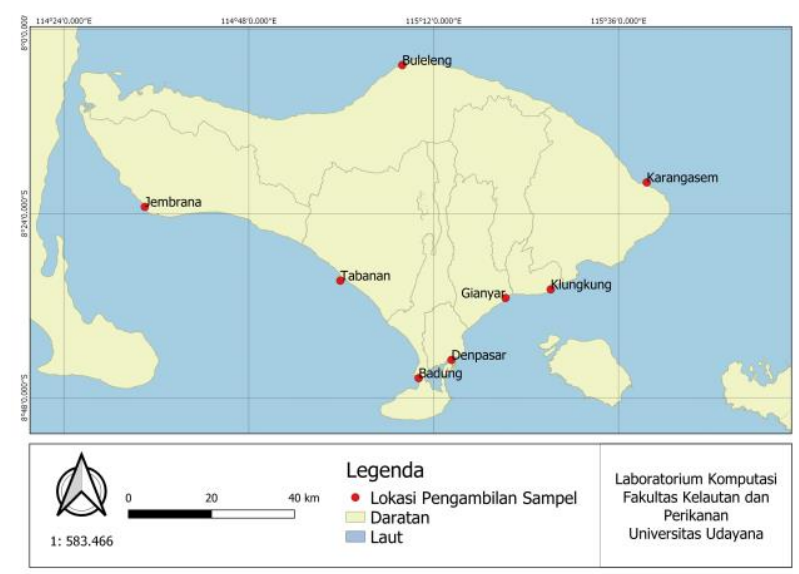

Gambar 1. Peta Lokasi Pengambilan Sampel Ikan

Sampel ikan dikumpulkan secara random dari 6 nelayan pertama yang mendaratkan ikan di wilayah masing-masing yaitu wilayah Jembrana (pantai Desa Air Kuning), Buleleng (pantai Kubu Tambahan), Badung (PPI Kedonganan), Denpasar (Pantai Serangan), Klungkung (Pantai Kusamba), Karangasem (PPI Amed) Gianyar (Pantai Lebih) dan Tabanan (Pantai Soka).

\subsection{Metode Pengambilan Sampel}

Ikan laut konsumsi yang digunakan sebagai sampel pada penelitian ini adalah ikan laut pelagis yang didaratkan oleh nelayan tradisional. Ikan pelagis merupakan ikan yang hidupnya bergerombol dan dapat ditemukan pada lapisan permukaan sampai kedalaman sekitar $200 \mathrm{~m}$. Sementara mikroplastik secara umum memiliki densitas yang lebih rendah dibandingkan air laut, sehingga konsentrasi tertinggi akan berada pada lapisan permukaan perairan laut (Sharma and Chatterjee., 2017). Penentuan jumlah nelayan dan jumlah ikan yang diambil pada tiap nelayan didasarkan pada penelitian yang telah dilakukan oleh Rochman et al., (2015) dan Kuhn Sussane et al., (2019) ikan dipilih secara random pada setiap daerah pendaratan ikan. Jumlah sampel ditentukan berjumlah 5-12 untuk merepresentasikan ikan tangkapan yang ada di setiap wilayah. Pada dasarnya ikan telah didapatkan secara random oleh nelayan dari hasil menangkap, sehingga sampel ikan telah dapat merepresentasikan ikan yang ada pada wilayah penangkapan nelayan tradisional. Sampel yang telah dikumpulkan kemudian disimpan dalam kotak pendingin (coolbox) yang kemudian dilanjutkan dengan proses identifikasi di laboratorium.

\subsection{Metode Wawancara}

Metode wawancara dilakukan untuk membuat peta partisipatif lokasi penangkapan ikan oleh nelayan tradisional di setiap wilayah pendaratan ikan. Wawancara dengan nelayan dilakukan untuk mengetahui lokasi nelayan menangkap ikan dengan menggunakan peta buta wilayah perairan Bali, mengetahui jenis ikan yang ditangkap, serta alat tangkap yang digunakan dalam menangkap ikan. Hasil dari wawancara kemudian dijadikan dasar dalam pembuatan peta partisipatif lokasi penangkapan ikan.

\subsection{Analisis Mikroplastik Pada Saluran Pencernaan Ikan}

Identifikasi mikroplastik menggunakan metode yang telah dikembangkan oleh Rochman et al., (2015). Sampel ikan didokumentasikan dan diidentifikasi spesiesnya, lalu diukur panjang (total length) dan berat dari sampel ikan. Proses identifikasi spesies ikan didasarkan pada buku Market Fishes of Indonesia yang ditulis oleh White et al., (2013). Selanjutnya ikan dibedah menggunakan dissecting set dan saluran pencernaannya diangkat lalu ditimbang beratnya menggunakan timbangan digital laboratorium (KERN) dan telah dilakukan kalibrasi pada timbangan. Setelah ditimbang, saluran pencernaan dari ikan diletakkan dalam gelas ukur, setiap gelas yang terdapat saluran pencernaan ikan diisi dengan larutan $\mathrm{KOH}(10 \%)$ dengan perbandingan 3:1 atau sampai saluran pencernaan dari ikan terendam lalu diinkubasi selama 24 jam pada suhu $60^{\circ} \mathrm{C}$. Hal ini dilakukan untuk menghancurkan saluran pencernaan ikan (organik). Jika masih ada sisa saluran pencernaan ikan pada tahap ekstraksi menggunakan $\mathrm{KOH} 10 \%$ maka perlu dilakukan ekstraksi kedua yaitu dengan menambahkan $\mathrm{H} 2 \mathrm{O} 2 \quad(3 \%)$ sebanyak $5 \mathrm{ml}$ pada tiap sampel lalu didiamkan selama 24 jam dengan suhu ruangan (Yudhantari et al., 2019). Setelah saluran pencernaan dari ikan hancur, selanjutnya disaring menggunakan kain saring dengan ukuran mesh sebesar $120 \mu \mathrm{m}$ untuk memudahkan penyaringan sampel (Yudhantari et al., 2019). Sampel yang telah tersaring, dibilas dengan aquades lalu dipindahkan ke kertas saring whatman yang berukuran $11 \mu \mathrm{m}$ lalu dilapisi dengan alumunium foil. Kemudian sampel dikeringkan dengan oven untuk mempermudah proses identifikasi. Sampel yang sudah kering lalu diidentifikasi dengan panduan menurut Viršek et al., (2016).

Identifikasi mikroplastik pada sampel saluran pencernaan ikan dilakukan dengan menggunakan mikroskop Olympus CX21 dengan perbesaran $4 x / 0.10$. Sampel pada kertas whatman dipindahkan ke cawan petri untuk memudahkan proses identifikasi. Untuk mendokumentasikan partikel mikroplastik digunakan software OptiLab ukuran mikroplastik yang teridentifikasi diukur menggunakan software Image Raster.

\subsection{Quality control \& quality assurance}

Proses pengolahan sampel di laboratorium dilakukan dengan memperhatikan quality control dan quality assurance. Untuk menjaga sampel tidak terkontaminasi oleh material plastik dalam proses analisis di laboratorium, maka selama proses pengolahan sampel ditetapkan protokol dengan menggunakan sarung tangan berbahan polimer dan jas laboratorium berbahan katun, serta seluruh alat alat yang digunakan dilakukan proses sterilisasi menggunakan aquades. Selama proses identifikasi dilakukan kontrol yaitu dengan meletakkan kertas saring whatman di sisi sisi mikroskop untuk melihat adanya kontaminasi dari luar (Purwiyanto et al., 2020). Tidak ditemukan adanya fiber plastik berwarna putih yang merupakan bahan dari kain saring pada kertas saring yang mengindikasikan tidak adanya kontaminasi udara. 


\subsection{Kelimpahan Mikroplastik Pada Ikan}

Kelimpahan mikroplastik dihitung menggunakan metode berdasarkan penelitian yang dilakukan oleh Boerger et al., (2010), dengan persamaan sebagai berikut:

$$
\text { kelimpahan }\left(\frac{\text { partikel }}{\text { ikan }}\right)=\frac{\sum \text { partikel mikroplastik }}{\sum \text { ikan }}
$$

\section{Hasil dan Pembahasan}

\subsection{Daerah dan Hasil Tangkapan Ikan}

Berdasarkan hasil dari wawancara yang telah dilakukan dengan nelayan yang menangkap ikan di perairan Bali, didapatkan data lokasi penangkapan ikan di tiap lokasi dalam peta partisipatif pada Gambar 2:

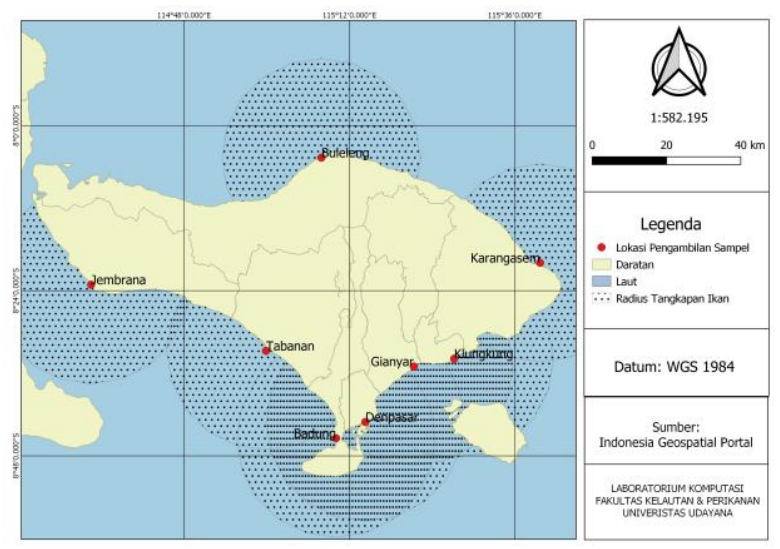

Gambar 2. Peta Partisipatif Lokasi Penangkapan Ikan

Nelayan yang menangkap ikan di perairan Bali Sebagian besar menggunakan jaring untuk menangkap ikan. Jarak nelayan menangkap ikan dari bibir pantai adalah berkisar 1-30 km.

Tabel 1. Sampel Ikan Yang Dikumpulkan Dari Nelayan

\begin{tabular}{ccccc}
\hline & $\begin{array}{c}\text { Decapterus } \\
\text { spp }\end{array}$ & $\begin{array}{c}\text { Auxis } \\
\text { rochei }\end{array}$ & $\begin{array}{c}\text { Rastrelliger } \\
\text { spp }\end{array}$ & $\begin{array}{c}\text { Sardinella } \\
\text { lemuru }\end{array}$ \\
\hline $\begin{array}{c}\text { Buleleng (Kubu } \\
\text { Tambahan) }\end{array}$ & 5 & 4 & 3 & - \\
$\begin{array}{c}\text { Tabanan (Pantai } \\
\text { Soka) }\end{array}$ & - & - & 2 & 3 \\
$\begin{array}{c}\text { Badung (PPI } \\
\text { Kedonganan) } \\
\text { Klungkung } \\
\text { (Pantai Kusamba) }\end{array}$ & - & 4 & - & 8 \\
$\begin{array}{c}\text { Karangasem (PPI } \\
\text { Amed) }\end{array}$ & 5 & - & - & - \\
$\begin{array}{c}\text { Gianyar (Pantai } \\
\text { Lebih) }\end{array}$ & - & 4 & 3 & - \\
$\begin{array}{c}\text { Jembrana (Pantai } \\
\text { Desa Air Kuning) } \\
\text { Denpasar }\end{array}$ & - & 12 & - & - \\
(Serangan) & - & 12 & - & - \\
\hline Total & 22 & 48 & 8 & 11 \\
\hline Total Jumlah Ikan & & & & \\
\hline
\end{tabular}

Tabel 1 merupakan sampel ikan yang dikumpulkan pada setiap wilayah pendaratan ikan. Sampel ikan yang didapat dari nelayan yang mendaratkan ikan di Bali didapat sebanyak 89 ekor ikan. Jenis sampel ikan yang didapat adalah Decapterus spp (selayang) sebanyak 22 ekor, Auxis rochei (tongkol) sebanyak 48 ekor, Rastrelliger spp (kembung) sebanyak 8 ekor dan Sardinella lemuru sebanyak 11 ekor.

\subsection{Jumlah dan Jenis Mikroplastik}

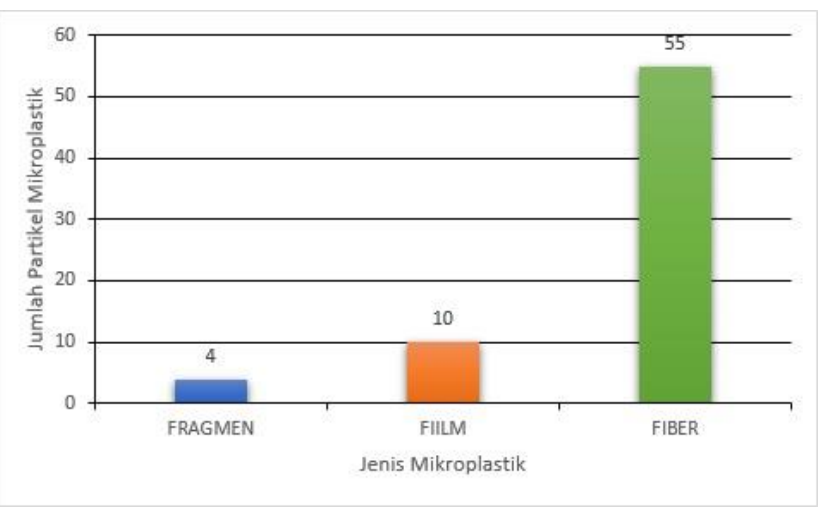

Gambar 3. Jenis Mikroplastik Yang Ditemukan

Hasil identifikasi mikroplastik pada saluran pencernaan sampel ikan didapatkan bahwa 39 ekor dari 89 ekor sampel ikan terkontaminasi oleh mikroplastik. Jenis mikroplastik yang ditemukan adalah fragmen sebanyak 4 partikel, film sebanyak 10 partikel dan fiber sebanyak 55 partikel dengan total 69 partikel mikroplastik dan 1 partikel mesoplastik berjenis fragmen.

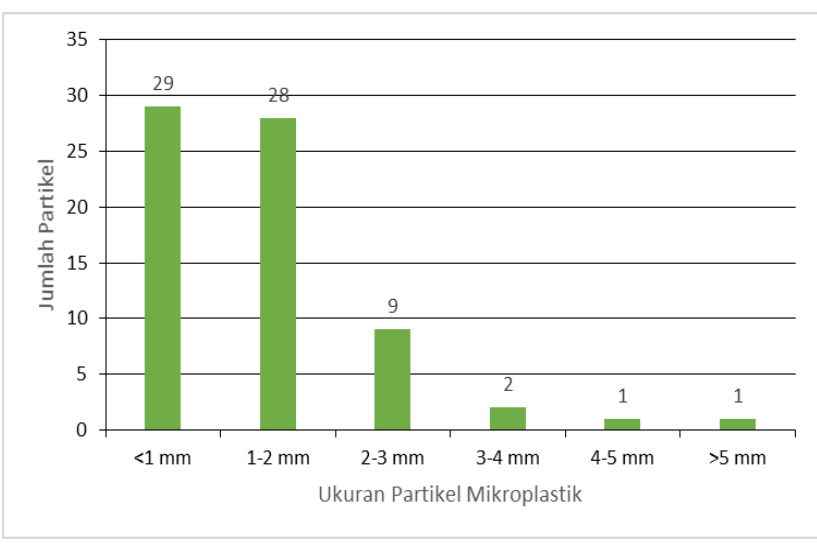

Gambar 4. Ukuran Partikel Mikroplastik Yang Ditemukan

Partikel mikroplastik yang ditemukan di saluran pencernaan ikan memiliki ukuran $0.32 \mathrm{~mm}-22 \mathrm{~mm}$. Konsumsi mikroplastik dapat menyebabkan kerusakan pada saluran pencernaan dan bahwa toksisitas mikroplastik sangat tergantung pada ukurannya (partikel ukuran sedang 1,0 mm menunjukkan efek terbesar), daripada komposisi mereka (Lei et al., 2018). Jumlah dan jenis mikroplastik dapat dilihat pada Gambar 3. Fiber merupakan jenis plastik yang dapat berasal dari bahan tekstil, benang pancing atau tali (GESAMP, 2016). Film merupakan lembaran plastik yang dapat berasal dari kantong plastik atau bungkus makanan, dan fragmen merupakan jenis plastik yang dapat berasal dari pecahan hard plastic (GESAMP, 2016). Kertas whatman sebagai kontrol di cek sebelum dan sesudah mengidentifikasi sampel pada mikroskop. Hasil dari kontrol menunjukkan tidak ada kontaminasi dari luar yaitu tidak ditemukannya mikroplastik atau benda apapun yang ada di kertas whatman. Adapun jenis mikroplastik yang ditemukan pada saluran pencernaan ikan yang di dapat dari perairan Bali dapat dilihat pada Gambar 5: 

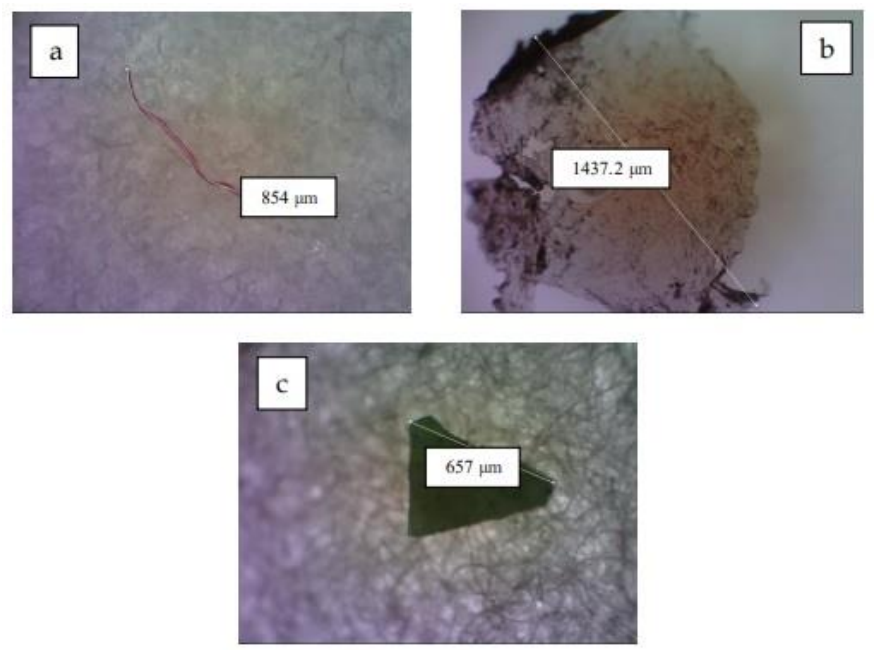

Gambar 5. Jenis Mikroplastik Yang Ditemukan: (a) Fiber (b) Film (c) Fragmen

Fiber merupakan jenis partikel mikroplastik yang paling melimpah. Ukurannya bisa pendek atau panjang, dengan ketebalan dan warna yang berbeda. Film/soft plastic bentuknya tidak teratur, tetapi dibandingkan dengan fragmen, jenis film lebih tipis dan fleksibel dan biasanya transparan. Jenis fragmen bentuknya kaku, tebal, dan bentuknya tidak beraturan dan memiliki berbagai warna yang berbeda. (Virsek et al., 2016). Penelitian mengenai karakteristik mikroplastik pada daerah feeding ground pari manta Nusa Penida oleh Argeswara et al. (2019) menunjukkan bahwa dari keseluruhan sampel mikroplastik, jenis mikroplastik terbanyak ditemukan adalah jenis fragmen, film, fiber dan jenis foam.

Tabel 2. Warna Mikroplastik Yang Ditemukan

\begin{tabular}{ccccc}
\hline & Fragmen & Film & Fiber & TOTAL \\
\hline Hitam & 5 & 4 & 3 & - \\
Biru & - & - & 2 & 3 \\
Merah & - & 4 & - & 8 \\
Hijau & 12 & - & - & - \\
Transparan & 5 & 4 & 3 & - \\
Krem & - & 12 & - & - \\
Coklat & - & 12 & - & - \\
\hline
\end{tabular}

Pada Tabel 2 dapat dilihat bahwa warna dominan dari mikroplastik yang ditemukan pada sampel ikan adalah warna hitam (38 partikel), diikuti oleh merah (11 partikel), clear/transparan (8 partikel), biru (6 partikel), cream (2 partikel), dan coklat (1 partikel). Mikroplastik jenis fragmen memiliki 2 buah warna yaitu warna hijau dan cream, jenis film memiliki 3 buah warna yaitu merah, hijau dan clear/transparan, dan jenis fiber memiliki 4 buah warna yaitu hitam, biru, merah dan coklat. Kelimpahan mikroplastik tertinggi berwarna hitam belum dapat dijelaskan pada penelitian ini, karena makanan dari ikan sendiri baik itu plankton, crustacea dan lain lain memiliki beragam warna. Perlu dilakukan penelitian lebih lanjut kandungan dari mikroplastik berwarna hitam untuk mengetahui kemungkinan penyebab dominannya. Salah satu yang sering dianggap mempengaruhi konsumsi mikroplastik pada ikan adalah warna (Kuhn et al., 2015) karena mikroplastik memiliki beragam jenis warna dan bentuk yang menyerupai makanan ikan maka ikan mungkin salah mengira bahwa itu adalah makanannya (Foekama et al,. 2013). Menurut Alimi et al (2018), mikroplastik tak berwarna menyerap lebih banyak PCB daripada plastik berwarna.

\subsection{Kelimpahan Mikroplastik}

Dari 89 sampel ikan yang dianalisis, 39 (43.82\%) diantaranya mengandung mikroplastik dengan kelimpahan rata-rata 0.78 dengan standar deviasi (SD) 1.15 partikel mikroplastik per ikan. Kelimpahan mikroplastik dari Decapterus spp, Auxis Rochei, Rastrelliger spp dan Sardinella lemuru masing masing dapat dilihat pada Tabel 3 .

Tabel 3. Sampel Jenis ikan

\begin{tabular}{ccccc}
\hline Spesies & $\begin{array}{c}\text { Jumla } \\
\text { h Ikan } \\
(\mathbf{N})\end{array}$ & $\begin{array}{c}\text { Jumlah Ikan } \\
\text { Yang } \\
\text { Terkontamina } \\
\text { si }\end{array}$ & $\begin{array}{c}\text { Jumlah } \\
\text { Mikroplasti } \\
\mathbf{k}\end{array}$ & $\begin{array}{c}\text { Kelimpah } \\
\text { an Per } \\
\text { Jenis Ikan } \\
( \pm \text { SD })\end{array}$ \\
\hline $\begin{array}{c}\text { Decapteru } \\
\text { s spp }\end{array}$ & 21 & 13 & 22 & $1.05 \pm 1.12$ \\
$\begin{array}{c}\text { Auxis } \\
\text { rochei }\end{array}$ & 52 & 16 & 33 & $0.62 \pm 1.19$ \\
$\begin{array}{c}\text { Rastrellig } \\
\text { er spp }\end{array}$ & 5 & 2 & 2 & $0.4 \pm 0.55$ \\
$\begin{array}{c}\text { Sardinella } \\
\text { lemuru }\end{array}$ & 11 & 8 & 13 & $1.18 \pm 1.08$ \\
\hline
\end{tabular}

Kelimpahan mikroplastik tertinggi terdapat pada jenis ikan Sardinella lemuru dengan kelimpahan sebesar $1.18 \pm 1.08$ partikel per ikan. Karena ikan Sardinella lemuru merupakan ikan yang cara makannya dengan menyaring makanan sehingga ada kemungkinan mikroplastik ikut masuk secara tidak sengaja pada proses makan

Pada penelitian ini, ikan yang didapatkan terbagi menjadi 2 jenis cara makan yaitu carnivore dan filter feeder. Ikan yang termasuk carnivore adalah ikan jenis Auxis rochei dan Decapterus spp hal ini didasarkan pada penelitian menurut (Hajjeji G et al., 2018,Jaiswar et al., 1993 dan Lubis et al., 2019) bahwa ikan jenis Auxis rochei dan Decapterus spp merupakan ikan carnovire yang makanannya berupa ikan ikan kecil, krustasea dan moluska. Ikan yang termasuk filter feeder adalah ikan Sardinella lemuru (lemuru) dan Rastrelliger spp (kembung), hal ini didasarkan pada penelitian menurut (Affandi, 2009 dan Hulkoti SH et al., 2013) bahwa ikan lemuru dan ikan kembung merupakan hewan filter feeder yang makanannya berupa plankton.

Tabel 4. Kelimpahan Berdasarkan Cara Makan

\begin{tabular}{ccccc}
\hline & $\begin{array}{c}\text { Jumlah } \\
\text { Jumlah } \\
\text { Ikan }\end{array}$ & $\begin{array}{c}\text { Ikan } \\
\text { Yang } \\
\text { Terkonta } \\
\text { minasi }\end{array}$ & $\begin{array}{c}\text { Jumlah } \\
\text { Mikropla } \\
\text { stik }\end{array}$ & Kelimpahan ( \\
\hline $\begin{array}{c}\text { Carnivore } \\
\text { Filter }\end{array}$ & 72 & 28 & 54 & $0.75 \pm 1.18$ \\
feeder & 16 & 10 & 15 & $0.94 \pm 0.99$
\end{tabular}

Kelimpahan mikroplastik tertinggi terdapat pada sampel ikan yang cara makannya dengan menyaring makanan (filter feeder) yaitu sebesar $0.94 \pm 0.99$ partikel/ikan dengan persesentase ikan yang terkontaminasi mikroplastik sebesar $62.5 \%$. Ikan mengkonsumsi mikroplastik pada proses makan dalam kolom air, karena ukurannya yang sangat kecil maka mikroplastik tidak sengaja ikut tertelan oleh ikan (Boerger et al., 2010). Karena beragamnya warna, ukuran, dan bentuk dari mikroplastik, ikan mungkin salah mengira bahwa itu adalah makanannya (Foekama et al., 2013). Setelah dicerna, mikroplastik dapat melewati usus atau dapat dipertahankan dalam saluran pencernaan (Browne et $a l ., 2008)$ dengan kemungkinan adanya efek fisik dan kimia yang 
potensial. Mikroplastik berbahaya bagi organisme karena dapat bergerak/berpindah melalui jaringan makanan (Ivar do Sul and Costa, 2014) yang telah terdeteksi pada zooplankton, bivalvia, krustasea, dan ikan (Hossain et al., 2019).

Pada hasil penelitian ditemukan bahwa kelimpahan mikroplastik pada ikan carnivore lebih kecil dari kelimpahan ikan filter feeder, hal ini dikarenakan makanan dari ikan carnivore belum tentu sudah atau telah mengkonsumsi mikroplastik jadi mungkin hal itulah yang mennyebabkan kelimpahan mikroplastik pada ikan filter feeder lebih tinggi. Sebuah penelitian telah menunjukkan bahwa kerang-kerangan (termasuk krustasea dan bivalvia), dan beragam spesies ikan yang penting secara komersial sering terkontaminasi oleh mikroplastik, dimana manusia menjadi terpapar oleh partikel-partikel mikroplastik dan bahan kimia yang dikandungnya (Bouwmeester et al., 2015; GESAMP, 2016). 25 spesies yang berkontribusi besar terhadap penangkapan ikan global (FAO, 2016) 11 diantaranya ditemukan mengandung mikroplastik. Bahan kimia yang ada pada mikroplastik dapat terakumulasi dalam jaringan ikan (Rochman $e$ al., 2015) yang dapat terakumulasi pada tingkat trofik yang lebih besar seperti mamalia laut dan manusia (Hossain et al., 2019).

\section{Kesimpulan}

Kelimpahan mikroplastik pada ikan hasil tangkapan di perairan Bali adalah 0.78 partikel/ikan dengan ikan yang terkontaminasi sebanyak $43.82 \%$ yang menandakan bahwa ikan laut konsumsi pada perairan Bali telah tercemar oleh mikroplastik. Tercemarnya ikan konsumsi di Bali oleh mikroplastik dapat meningkatkan resiko kesehatan bagi masyarakat yang mengkonsumsi. Upaya pengelolaan lingkungan, utamanya pengelolaan sampah plastik yang baik sangat diperlukan untuk mengurangi pencemaran plastik di perairan Bali.

\section{Ucapan Terimakasih}

Pada kesempatan ini penulis ingin mengucapkan terima kasih kepada Fitra Cahya Prima dan Idam Bali Haryono yang membantu dalam proses pengambilan data sampel ikan, dan kepada Isna Siyami, Felixita Abigail dan Panji Pamungkas yang telah membantu dalam proses pengolahan data sampel mikroplastik.

\section{Daftar Pustaka}

Affandi R, Sjafei DS, Rahardjo MF, Sulistiono. 2009. Fisiologi Ikan Pencernaan dan Penyerapan makanan. IPB Press. Bogor. 240 halaman.

Andrady AL. 2011. Microplastics in the marine environment. Marine Pollution Bulletin. 62 (8): 1596-1605.

Argeswara JKP. 2019. Karakteristik mikroplastik pada daerah feeding ground pari manta, big manta bay, nusa penida. [skripsi]. Bali : Fakultas Kelautan Dan Perikanan, Universitas Udayana. 60 hal

Arthur C, Baker J, Bamford H., (Eds.), 2009. Effects and fate of micro-plastic marine debris. Proceedings of the International Research Workshop on the Occurrence. 9-11 September 2008. NOAA Technical Memorandum NOS-OR\&R-30.

Bali Partnership. 2019. Inilah data dan sumber sampah terbaru di bali. Mongabay: https://www.mongabay.co.id/2019/07/02/inilah-data-dansumber-sampah-terbaru-di-bali/ [12 November 2019]

Barboza LGA, Vethaak AD, Lavorante BRBO, Lundebye AK, Guilhermino L. 2018. Marine microplastic debris; an emerging issue for food security, food safety and human health. Marine Pollution Bulletin. Vol 133 : 336348

Boerger CM, Lattin GL, Moore SL, Moore CJ. 2010. Plastic ingestion by planktivorous fishes in the North Pacific Central Gyre. Marine Pollution Bulletin. Vol 60 : 2275-2278.
Bouwmeester, H., Hollman, P.C.H., Peters, R.J.B., 2015. Potential health impact of environmentally released micro- and nanoplastics in the human food production chain: experiences from nanotoxicology. Environ. Sci. Technol. 49, 8932-8947.

Browne MA. 2015. Sources and pathways of microplastics to habitats. In Marine Anthropogenic Litter. Springer International Publishing pp. 229-244.

Browne M, Dissanayake A, Galloway T, Lowe D, Thompson R. 2008. Ingested microscopic plastic translocates to the circulatory system of the mussel, Mytilus edulis. Environmental Science Technology 42: 50265031

Food and Agriculture Organization. 2016. The State of World Fisheries and Aquaculture 2016. In: Contributing to Food Security and Nutrition for All. Rome, (200 pp). http://www.fao.org/3/a-i5555e.pdf

Foekama EM, Gruijter CD, Mergia MT, vanFraneker JA, Murk ATJ, Koelmans AA. 2013. Plastic in North Sea Fish. Environ. Sci. Technol. 47, $8818-8824$

GESAMP. 2015. Sources, fate and effects of microplastics in the marine environment: a global assessment. In: Kershaw PJ (ed) (IMO/FAO/UNESCO-IOC/UNIDO/WMO/IAEA/UN/UNEP/UNDP Joint Group of Experts on the Scientific Aspects of Marine Environmental Protection). Rep Stud GESAMP No. 90, pp 96

GESAMP, 2016. Sources, fate and effects of microplastics in the marine environment: part two of a global assessment. In: Kershaw, P.J., Rochmann, C.M. (Eds.), (IMO/FAO/UNESCOIOC/UNIDO/WMO/IAEA/UN/UNEP/UNDP Joint Group of Experts on the Scientific Aspects of Marine Environmental Protection). Rep. Stud. GESAMP No. 93 (220 p).

Hajjeji G, Missaoui H, Jarboui O. 2018. Preliminary Stomach Contents Analysis Of Bullet Tuna Auxis Rochei (Risso, 1810) In Tunisian Waters Collect. Vol. Sci. Pap. ICCAT, 75(1): 86-94

Hossain MS, Sobhan F, Uddin MN, Sharifuzzaman SM, Chowdhury SR, Sarker S, Chwdhury MSN. 2019. Microplastics in fishes from the Northern Bay of Bengal. Science of the Total Environment 690 : 821-830

Hulkoti SH, Shivaprakash SM, Anjanayappa HN, Somashekara SR, Benakappa S, Naik ASK, Prasad LG, Kumar J. 2013. Food and Feeding Habits of Mackerel Rastrelling kanagurta (Cuvier) from Mangalore Region. Environment \& Ecology 31 (2A) : 672-675

Jaiswar AK, George JP, Gulati DK, Swamy RP. 1993. A Study On LengthWeight Relationship, Food And Feeding Habits Of Indian Scad, Decapterus Russell (Ruppell, 1830) Along The Northwest Coast Of India. Journal Of The Indian Fisheries Association 23: 1.6

Kühn S, Rebolledo ELB, van Franeker JA. 2015. Deleterious Effect of Litter on Marine Life. pp 75-116 In: Bergmann, M., Gutow, L., and Klages, M. (eds). Marine Anthropogenic Litter. Springer, Berlin.

Lei L, Wu S, Lu s, Liu m, Song Y, Fu Z, Shi H, Raley-Susman KM, He D. 2018. Microplastic particles cause intestinal damage and other adverse effects in zebrafish Danio rerio and nematode Caenorhabditis elegans, Sci. Total Environ. 619: 1-8.

Lubis F, Adharini RI, Setyobudi E. 2019. Food Preference of Shortfin Scad (Decapterus macrosoma) at the Southern Waters of Gunungkidul Yogyakarta, Indonesia. JIPK. Volume 11 No 2.

Lusher AL, McHugh M, Thompson RC. 2013. Occurrence of microplastics in the gastrointestinal tract of pelagic and demersal fish from the English Channel. Marine Pollution Bulletin 67: 94-99

Purwiyanto AIS, Suteja Y, Trisna, Ningrum PS, Putri WAE, Rozirwan, Agustriani F, Fauziyah, Cordova MR, Koropitan. 2020. Concentration and adsorption of $\mathrm{Pb}$ and $\mathrm{Cu}$ in microplastics: Case study in aquatic environment. Marine Pollution Bulletin 158: 111380

Rochman C, Akbar T, Susan L, Williams, Dolores V, Baxa, Rosalyn L, Jeffrey T, Miller, Foo-Ching Teh, Shinta Werorilangi, Swee J. 2015. Anthropogenic debris in seafood: Plastic debris and fibers from textiles in fish and bivalves sold for human consumption. Scientific Reports. 5(1) : 1-10. https://doi.org/10.1038/srep14340

Rochman CM (2015) The complex mixture, fate and toxicity of chemicals associated with plastic debris in the marine environment. In: Bergmann M, Gutow L, Klages M (eds) Marine Anthropogenic Litter. Springer, pp 117-140 doi http://dx.doi.org/10.1007/978-3-319-16510-3_5

Sharma S, Chatterjee S. 2017. Microplastic Pollution, a Threat to Marine Ecosystem and Human Health: a Short Review. Environ Sci Pollut Res 24 : 21530-21547

Viršek KM, Palatinur A, Koren S, Peterlin M, Horvat P, Krzan A. 2016. Protocol for microplastics sampling on the sea surface and sample analysis. Journal of Visualized Experiments: JoVE. 118 : $1-9$. https://doi.org/10.3791/55161 
Wang J, Tan Z, Peng J, Qiu Q, Li M. 2016. The Behaviors of Microplastics in The Marine Environtment. Marine Environmental Research 113 7-17.

White WT, Last PR, Dharmadi, Faizah R, Chodrijah U, Prisantoso BI, Pogonoski JJ, Puckridge M and Blaber SJM. 2013. Market fishes of Indonesia. ACIAR Monograph No. 155. Australian Centre for International Agricultural Research: Canberra. 438 pp.

Yudhantari CIAS, Hendrawan IG, Puspitha NLPR. 2019. Kandungan mikroplastik pada saluran pencernaan ikan lemuru protolan (Sardinella Lemuru) Hasil Tangkapan Di Selat Bali. Journal of marine research and technology. Volume $2: 48-52$ 